UNITED NATIONS CONFERENCE ON TRADE AND DEVELOPMENT

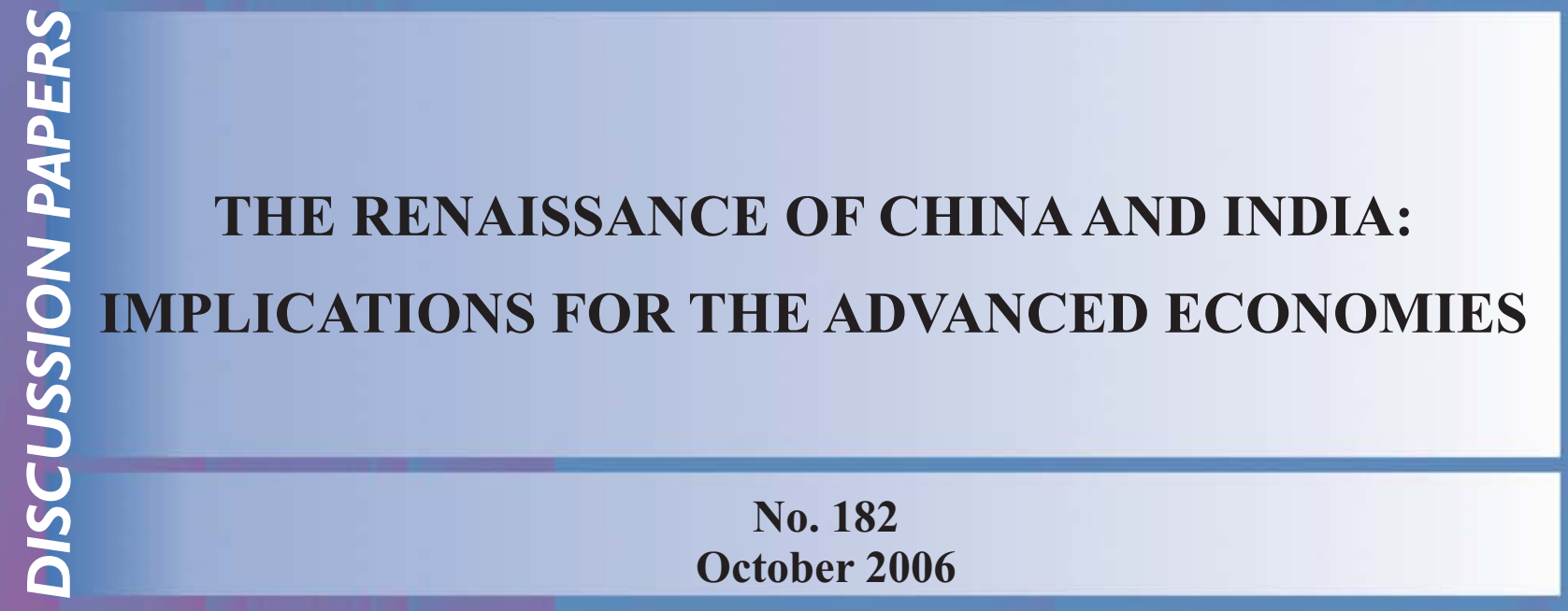





\title{
THE RENAISSANCE OF CHINA AND INDIA: IMPLICATIONS FOR THE ADVANCED ECONOMIES
}

\author{
Robert Rowthorn \\ Economics Faculty, Cambridge University \\ (Email: rer3@econ.cam.ac.uk)
}

No. 182

October 2006

I should like to thank Ha-Joon Chang, Andrew Glyn, Bill Martin, Joerg Mayer and Nobu Yokokawa for their valuable comments on earlier drafts of this paper 
The opinions expressed in this paper are those of the author and do not necessarily reflect the views of UNCTAD. The designations and terminology employed are also those of the author.

UNCTAD Discussion Papers are read anonymously by at least one referee, whose comments are taken into account before publication.

Comments on this paper are invited and may be addressed to the author, c/o the Publications Assistant, Macroeconomic and Development Policies Branch, Division on Globalization and Development Strategies, United Nations Conference on Trade and Development (UNCTAD), Palais des Nations, CH-1211 Geneva 10, Switzerland (Fax No: (4122) 9070274). Copies of Discussion Papers may also be obtained from this address.

New Discussion Papers are available on the website at http://www.unctad.org. 


\section{Contents}

Page

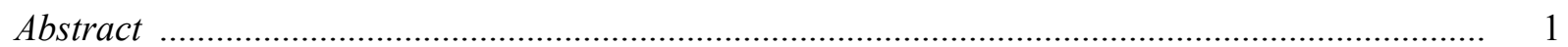

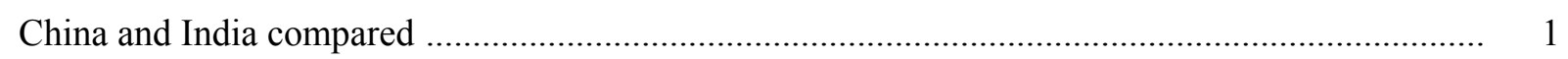

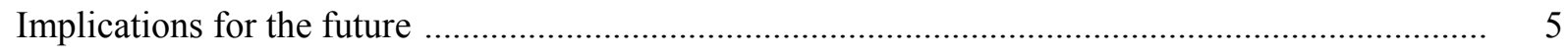

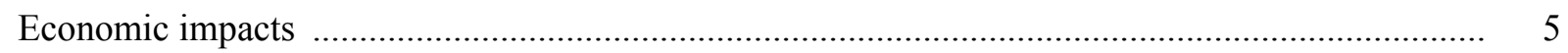

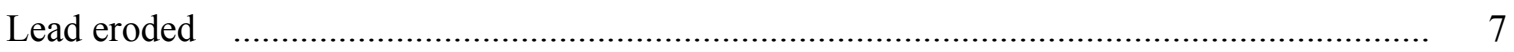

Scarce resources

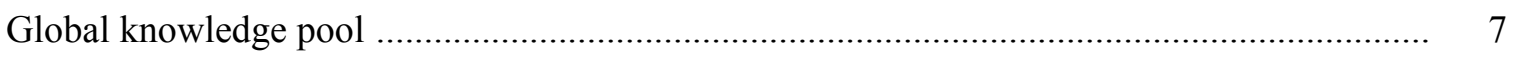

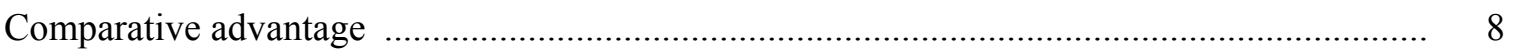

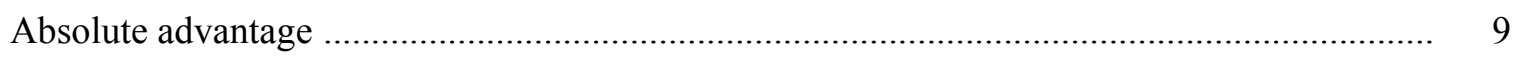

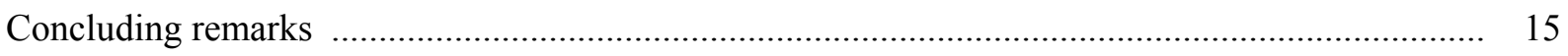



Appendix 1: Projected Chinese and Indian Growth .................................................................... 17

Appendix 2: A simple model and numerical example ............................................................. 19

Table

$1 \quad$ India, China and South Korea compared ..................................................................... 4

2 Most attractive global business locations: responses of experts and transnational corporations ................................................ 12

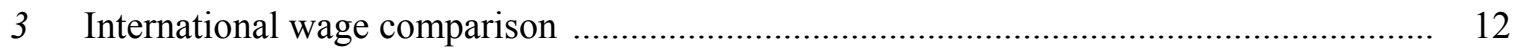

$4 \quad$ Real wages and dollar wages: a numerical example ..................................................... 13

5 Catching up with the USA: GDP per capita ............................................................ 17

6 Comparative and absolute advantage: a numerical example ............................................ 23

Figure

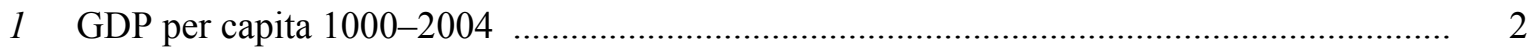

2 Projected development of China and India: 2004-2050 ................................................ 2

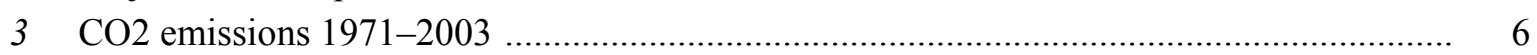

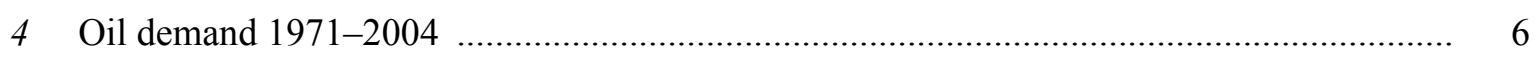

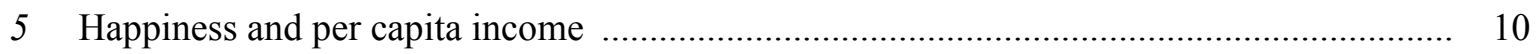

6 China and India: current account balance 1980-2005 ..................................................... 10

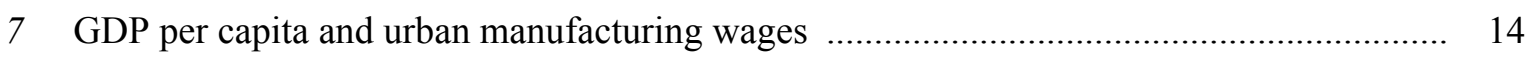

8 Financial performance of industrial companies ............................................................ 14 



\title{
The Renaissance OF China AND INDIA: IMPLICATIONS FOR THE ADVANCED ECONOMIES
}

\author{
Robert Rowthorn \\ Economics Faculty, Cambridge University \\ (Email: rer3@econ.cam.ac.uk)
}

\begin{abstract}
Using simple convergence equations, this paper projects that by mid-century per capita incomes in China and India will on average be about half the US level. In terms of total production, both countries should overtake the USA by 2050. Such developments will affect the advanced economies through several channels. The terms of trade of these economies will deteriorate as labour intensive imports, such as clothing or holidays, become more expensive when ultra-cheap supplies from China (and later India) dry up. Resource-based imports may also become more expensive in response to rising demand from China and India. Orders of magnitude suggest that such terms of trade losses may be fairly easy to absorb if they are spread over many years. On the positive side, as China and India develop they will become major innovators in their own right and the advanced countries will benefit by importing technology from them. The development of China and India may also affect the internal distribution of income within the advanced economies. If transnational corporations can earn higher profits by moving production to China and India they may use this as a credible threat to extract concessions from their existing workers in the advanced economies. An appendix to the paper presents a simple mathematical model and some numerical examples that inform the discussion in the text.
\end{abstract}

A thousand years ago, China and the region that is now India were the richest and most populous areas of the world. In terms of per capita income they were overtaken at first by certain countries in Western Europe, then by some of their European offshoots, such as the United States of America, and finally by some East Asian economies such as Japan and South Korea (Figure 1). This process has now gone into reverse and both China and India are catching up rapidly with the countries which had overtaken them. Barring some catastrophe, it seems inevitable that within the space of a few decades China and India will once again be the largest economies in the world and their per capita incomes will rise dramatically. This paper is concerned with the implications of this development for the existing advanced economies.

\section{China and India compared}

Both India and China have undergone a prolonged process of economic reform designed to promote capitalist development, in each case with notable success, although the process is more advanced in China.

China had a lower per capita income than India in 1980, but grew much faster and overtook India by 1990. Since then growth in China has been so fast that per capita income is now more than twice that of India. However, Indian growth is accelerating and many commentators predict that it is about to move onto a Chinese-style growth path. There are some major obstacles to be overcome if this is to be achieved. Infrastructure is poor in India and there is widespread illiteracy. In 2004, almost 24 per cent of the Indian population aged 15-24 was illiterate. This compares to only 5 per cent in China a decade ago and 1 per cent today. 
Figure 1

GDP PER CAPITA 1000-2004

(1990 International \$ at PPP)

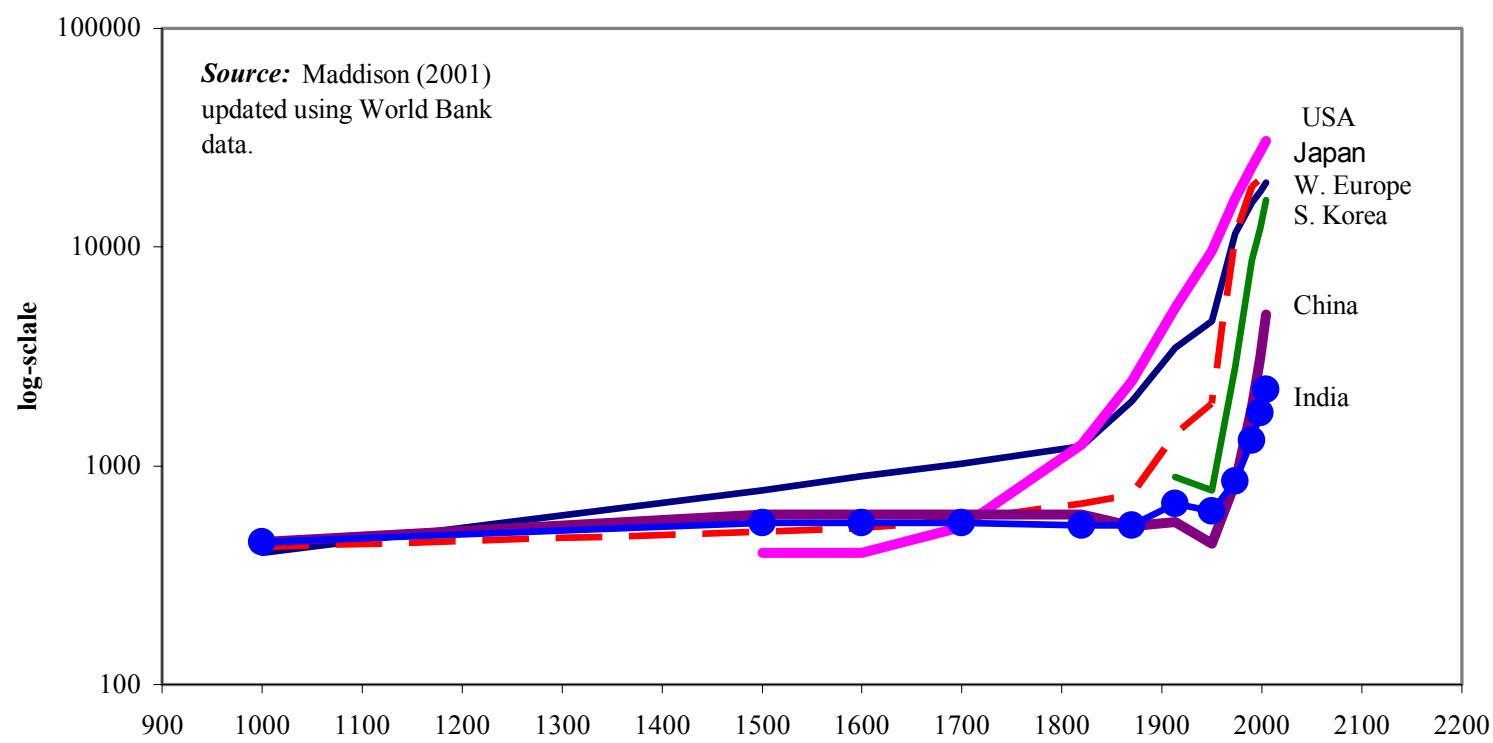

Figure 2

PROJECTED DEVELOPMENT OF CHINA AND INDIA: 2004-2050

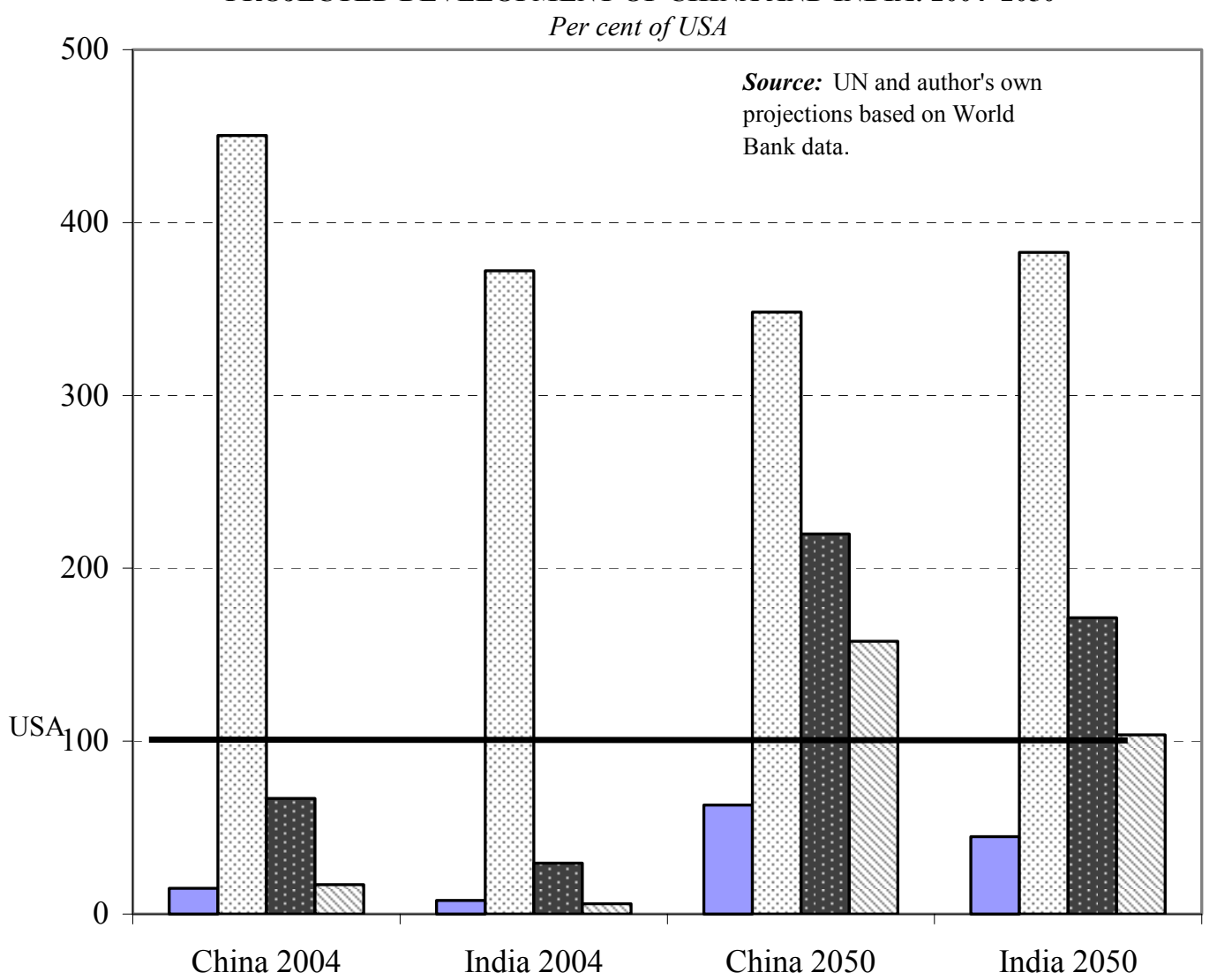

口GDP per capita (at PPP)

๑Population

GDP (at PPP)

Q GDP(at market exchange rate) 
Measured at purchasing power parity, per capita income in China is still less than one-sixth of the US level, but is growing extremely fast. Since 2000 per capita income has risen at 8.4 per cent a year as compared to 1.8 per cent in the USA. With these growth rates it would take China only 30 years to catch up with US per capita income. Until recently India's growth rate has been well below that of China and since 2000 its per capita income has grown at an average rate of 4.6 per cent a year. At this rate it would take 95 years for India to catch up with the USA.

The above projections are unrealistic for two reasons. Chinese growth is likely to slow down in the medium term and Indian growth has been accelerating. I have therefore produced some more realistic projections of my own. These projections assume that India will grow rapidly in the near future and that both China and India will eventually slow down as their per capita incomes begin to converge on the US level. The slowing down process is modelled using a standard convergence equation. Details are given in an appendix.

Figure 2 shows projected values of GDP per capita, population and total GDP in China and India in 2050. GDP per capita is measured at purchasing power parity (PPP), which is the standard method for comparing living standards. Total GDP is measured in two ways - at purchasing power parity and at market exchange rates. All quantities are shown relative to the USA. Taking the USA $=100$, it is projected that per capita GDP in China and India will be equal to 63 and 45 respectively by 2050. Both countries have, and will continue to have, much larger populations than the USA. As a result, despite their lower per capita incomes, both countries will rival or surpass the USA in terms of total production by the end of the period. The exact relationship depends on how GDP is measured. Using the PPP measure of total output, both China and India comfortably overtake the USA by 2050. Such a comparison is a bit misleading as a guide to the global power of these countries, because it gives too much weight to the output of non-traded services, such as health and retail distribution. Although valuable to the local residents, these items are of secondary importance in international affairs. The alternative is to use market exchange rates which give more weight to internationally traded items such as manufactured goods. However, even with this measure, total production in China is 60 per cent larger than in the USA by 2050, whilst India and the USA are about equal. The projections should not be taken literally, but they do indicate the orders of magnitude involved.

It is often said that India has a different growth path from China, with a greater role for modern services, a smaller role for manufacturing and a much lower investment rate (Das 1996, Dasgupta and Singh 2005). There is some truth in these claims but they should not be exaggerated. The lower investment rate in India is associated with slower economic growth than in China, and as growth accelerates in India the investment rate is likely to rise. India also has significant exports in IT-related areas such as software and call centres, whereas Chinese exports in these areas are still small. India's strength in services is indicated by the relatively high productivity in this sector. Services employ only 22 per cent of the Indian workforce but account for more than 50 per cent of value added (Table 1). However, the manufacturing sector is now growing rapidly and Prime Minister Manmohan Singh has recently announced a target of 12 per cent a year growth in manufacturing output. ${ }^{1}$ Indian manufacturing exports are also growing fast.

\footnotetext{
${ }^{1}$ rediff.com April 18, "PM's recipe for 10\% GDP growth"
} 
Table 1

INDIA, CHINA AND SOUTH KOREA COMPARED

\begin{tabular}{|c|c|c|c|c|c|}
\hline & India 2004 & China 1996 & China 2004 & Korea 1972 & Korea 1982 \\
\hline $\begin{array}{l}\text { GDP per capita } \\
\text { (PPP at } 2000 \text { international \$) }\end{array}$ & 2885 & 2971 & 5419 & 3014 & 5387 \\
\hline Exports as per cent GDP & 19.1 & 20.1 & 34.1 & 19.4 & 33.2 \\
\hline \multicolumn{6}{|l|}{ Per cent of employment: } \\
\hline Agriculture & $60.4^{*}$ & 47.7 & $44.1 * *$ & 50.5 & 32.1 \\
\hline Industry & $16.9 *$ & 25.5 & $21.2 * *$ & 17.9 & 27.9 \\
\hline Services & $22.7 *$ & $26.8^{+}$ & $34.7^{* *,+}$ & 31.7 & 40.1 \\
\hline \multicolumn{6}{|l|}{ Per cent of Value-Added: } \\
\hline Agriculture & 21.1 & 19.5 & 13.1 & 28.7 & 16.0 \\
\hline Industry & 27.1 & 47.5 & 46.2 & 26.2 & 37.0 \\
\hline Services & 51.7 & 33.0 & 40.7 & 45.1 & 47.0 \\
\hline Per cent urban & 28.5 & 32.2 & 39.6 & 43.6 & 60.1 \\
\hline
\end{tabular}

Sources: Employment: China: ILO Labor Statistics Database plus Banister (2005a), Table 4; services include activities not adequately defined. India: Dasgupta and Singh (2005), Table 3 adapted from Joshi (2004); agriculture includes mining; Korea: KSO website. Other data: World Bank World Development Indicators (Korean 1972 by extrapolation using Maddison (2001)).

Notes: $* 1999 / 2000$ (agriculture includes extraction); $* * 2002,{ }^{+}$includes activities not adequately defined.

The fact that India has a strong position in information technology has a number of advantages. Software exports have more than doubled in the past three years and in 2005-2006 India had a trade surplus of more than $\$ 22$ billion on such items, which is equivalent to one-sixth of total exports. A study by NASSCOM-McKinsey in 2005 examined the potential for Indian service exports in ITrelated areas. The study estimated that India now accounts for 65 per cent of the global market in offshore IT and 46 per cent of the global business process offshoring segment (BPO). It also estimated that the "total addressable market for global offshoring is approximately $\$ 300$ billion, of which $\$ 110$ billion will be offshored by 2010. India has the potential to capture more than 50 per cent of this opportunity and generate $\$ 60$ billion by growing at 25 per cent year-on-year till $2010 " 2$. If such a target could be achieved, IT-related service exports might reach 5 per cent of Indian GDP and perhaps a quarter of total exports of goods and services. This in itself would be a valuable contribution. India's strength in IT can also be very useful in manufacturing and other industries, helping them to raise productivity and develop new, high-value added products. Provided infrastructural and bureaucratic weaknesses do not stifle economic growth, India's strength in IT creates the potential for a spectacular performance in manufacturing over the coming years. Thus, IT-related services can contribute to economic growth, both in their own right and as a complement and stimulus for other activities.

So far, at least, IT-related services are less important for China and the manufacturing sector plays a much larger role. Manufacturing production has grown strongly in recent years, and industry as a whole, including construction, now accounts for 46 per cent of value-added. This is achieved with only 21 per cent of the workforce force, reflecting the relatively high productivity of Chinese manufacturing ${ }^{3}$. Despite the rapid growth of manufacturing output in China, the total number of people employed in this sector has actually fallen over the past decade. Massive labour shedding by old government enterprises has outweighed the creation of new jobs in the rest of the manufacturing sector. As incomes have risen and the country has urbanised, Chinese service employment has grown

\footnotetext{
${ }^{2}$ Noshir, Partner, McKinsey \& Company, www.nasscom.in/Nasscom/templates/NormalPage.aspx?id=2599.

${ }^{3}$ Official figures used by the ILO understate employment in manufacturing. The figure given here includes an adjustment due to Banister (2005).
} 
rapidly. Part of this reflects rising demand for services and part of it is because the service sector is acting like a sponge to absorb surplus from the countryside and the old state enterprises.

\section{Implications for the future}

It seems likely that within a few decades China and India will once again become the largest economies in the world and their per capita incomes will rise dramatically. There may still be poor areas and many poor individuals, but they will both have large and sophisticated manufacturing and service sectors. This will have many diverse implications. Both India and China will become great powers, with large well-equipped armed forces and the economic muscle to challenge the present global dominance of the United States. This will have profound implications for international politics as the world moves from a unipolar world to a multipolar one. There are also environmental issues to consider. For example, the modern economic growth of China and India has been accompanied by a trend growth in $\mathrm{CO}_{2}$ emissions which looks set to continue in the future (Figure 3). Their per capita emissions are unlikely to reach anything like the present US level, but with their huge populations, they are bound to become major polluters. Most scientists believe that a higher concentration of $\mathrm{CO}_{2}$ in the atmosphere contributes to higher average temperatures, although there is disagreement about the scale of this effect or its environmental consequences. Another example is oil. The consumption of oil by China has been increasing rapidly and it appears that China will soon overtake the USA as a user of this fuel (Figure 4). The Indian demand for oil is much lower, but if predictions of Indian growth are correct, the country's consumption of oil will also increase rapidly. These developments are likely to harm the rest of the world, although by how much is uncertain. A large increase in world oil demand could lead to global shortages and higher prices, thereby damaging countries which are heavily dependent on imported oil. These are just some examples of the environmental issues raised by the economic growth of China and India.

\section{Economic impacts}

As China and India develop, their trade will increase in volume and its composition will alter as they move up the value chain into so-called "knowledge intensive" activities. Judging by the experience of existing advanced economies, manufactured exports will continue to predominate in the case of China and they will become increasingly important for India. The Nasscom 2005 report mentioned above implies that India's IT-related service exports could eventually exceed $\$ 150$ billion dollars. One should take this claim with a pinch of salt since Nasscom is an organisation representing Indian IT firms. However, this does not alter the fact that IT-related services are at present a central component of India's exports and will continue to be so in the future. Nor does it alter the fact that India is likely to become a major exporter of sophisticated manufactures. As the Indian economy grows in both size and sophistication, the same will be true of its booming exports of both manufactures and services.

What is the potential for overall growth in Chinese and Indian trade? In 2004, Chinese exports were 34 per cent of GDP and for India the figure was 19 per cent (Table 1). China's figure is inflated by the fact that its manufacturing exports have a very high import content. As the two countries develop, these ratios may rise for a time but they are unlikely to reach the level of a small open economy such as South Korea whose exports were equal to 44 per cent of GDP in 2004. In the long-run, the trade ratios of China and India should eventually converge to a level that is more commensurate with their future status as economic giants. Within a few decades, both China and India will have huge domestic markets and they will produce for themselves most of the sophisticated goods and services required to 
6

Figure 3

CO2 EMISSIONS 1971-2003

MT per annum (log-scale)

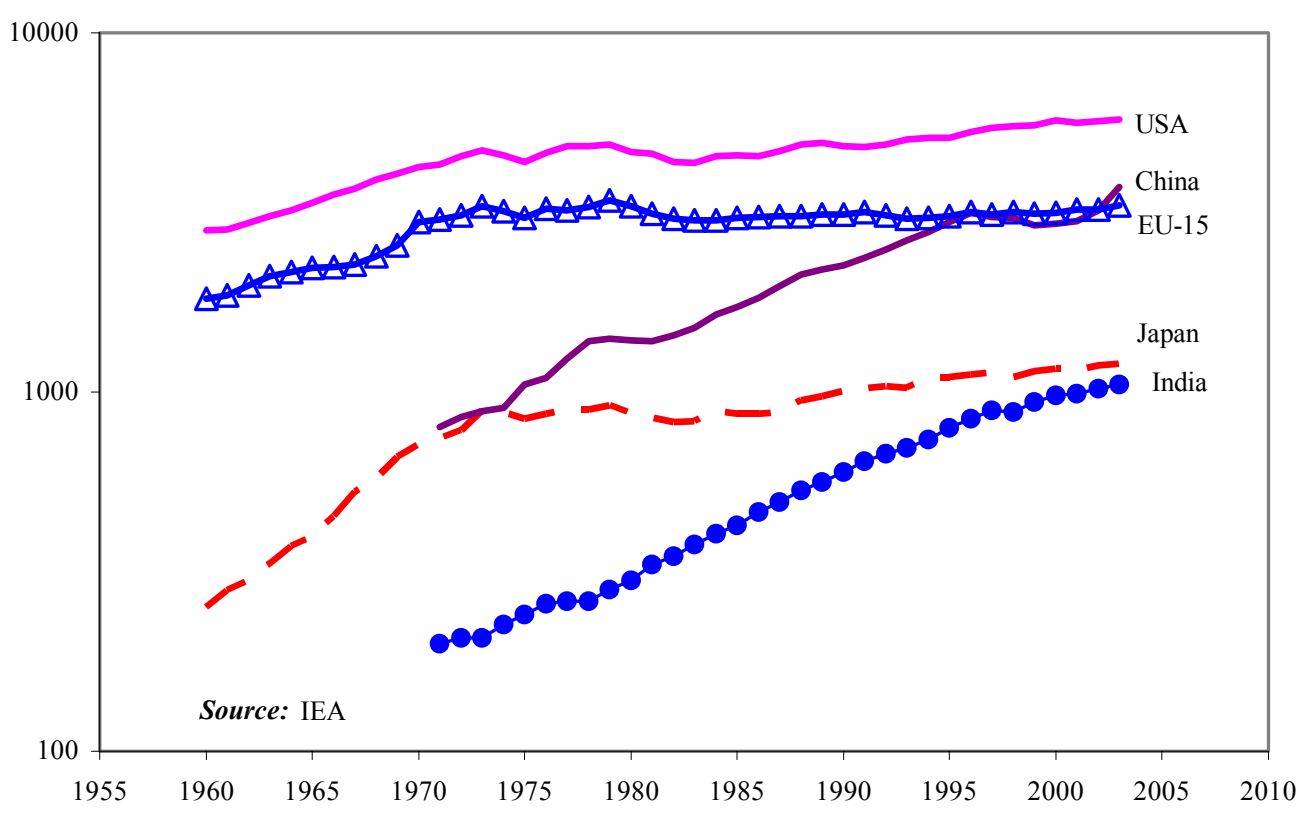

Figure 4

OIL DEMAND 1971-2004

'000 Tonnes per annum

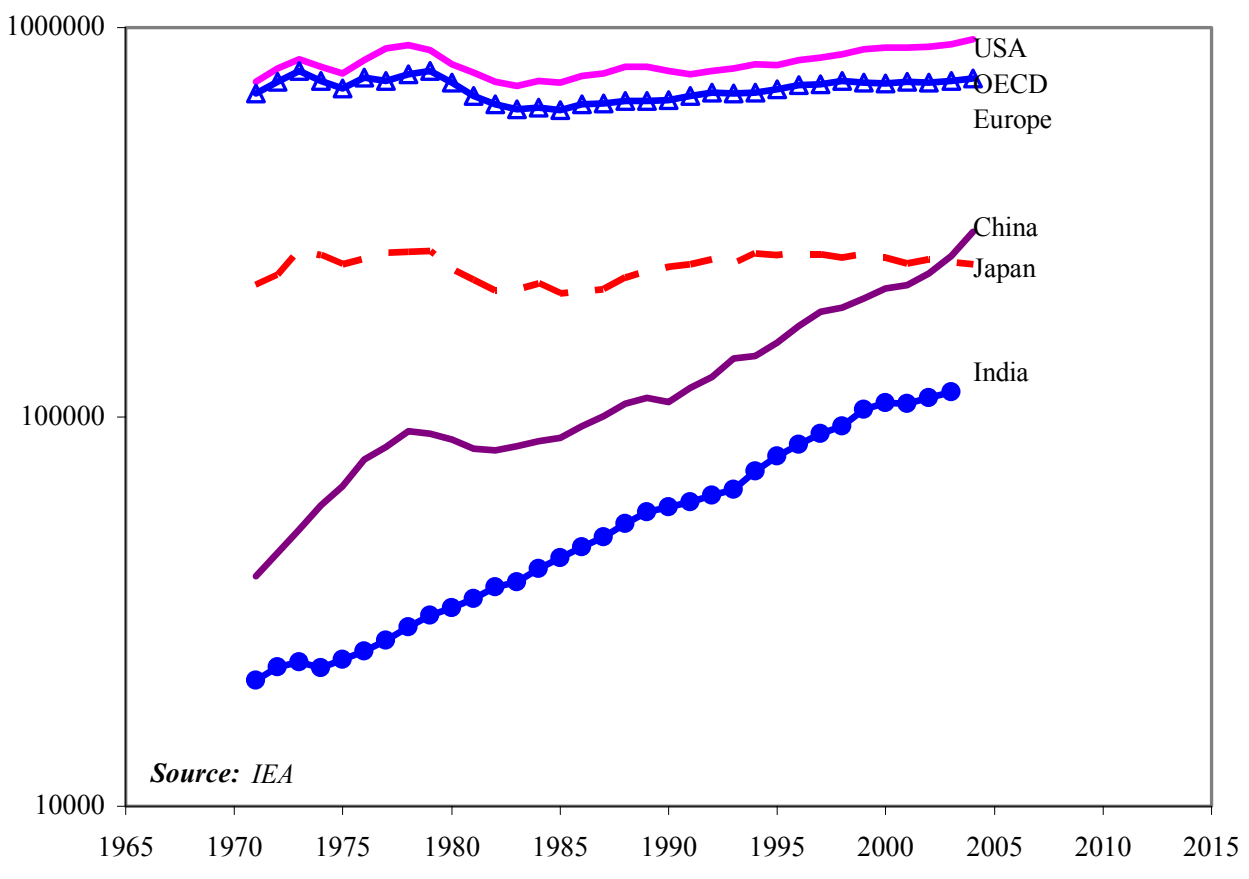


supply these markets. Foreign trade will still be important for them, but it is unlikely that their trade to GDP ratios will greatly exceed those of other large economies, such as the United States, the EU and Japan. If we exclude internal trade within the EU, in all of these economies total exports of goods and service are around 10-14 per cent of GDP. It is hard to believe that China and India will be much different. Even so, given the future size of their economies, and the future sophistication of their domestic production and exports, it seems inevitable that the development of these countries will have profound implications for the existing advanced economies.

The following is a brief outline of some of the main ways in which the advanced economies may be affected by the rise of China and India.

\section{Lead eroded}

The technological lead and relative income of today's rich countries will decline as other countries, such as China and India, begin to catch up with them. They will also be overtaken in terms of total production. This in turn will erode their military and political power, for as Paul Kennedy (1988) has argued, power in international affairs depends on relative, not absolute, economic strength. A dominant country, such as the USA, may continue to grow economically and its citizens may enjoy an ever rising standard of living, but its power will be undermined if its share in world production is greatly reduced. This is what happened to Britain in the $20^{\text {th }}$ century, and the same will happen to the USA in this century.

\section{Scarce resources}

The rapid growth of China and India will cause a large increase in the demand for certain natural resources, such as oil, which are important to the existing advanced economies (UNCTAD 2005a, Chapter 2). If the result is a steep rise in prices, the advanced economies will experience a loss of real income as their imports become more expensive, and they may also experience dislocation as they seek to adjust to the new scarcities. Some idea of the potential loss can obtained from existing trade statistics. The amount spent by the main advanced economies on imported fuels and mining products ranges from 2.1 per cent of GDP for the EU-25 to 2.7 per cent for Japan. This is the proportion by which real income in these countries would be reduced if prices were to double and if there were no change in consumption patterns or methods of production. This may seem like a lot, but spread over 25 years it is equivalent to only 0.1 per cent a year reduction in the growth rate.

\section{Global knowledge pool}

As other countries such as China and India develop, the global resources devoted to science and technology will increase several-fold. Some of the extra knowledge thereby obtained will be retained in the countries concerned and will be not be of benefit to other countries. However, much of this knowledge will diffuse into the rest of the world and will be available for exploitation by others. Just as China and India are importing technology from us today, we shall be able to import technology on an increasing scale from them in the future. In this way, the economic development of poorer countries may ultimately contribute to faster growth in the present rich countries. Moreover, by increasing the global resources devoted to research and development it may also promote the discovery of technologies that are more environmentally friendly and able to avoid the otherwise harmful effects of economic growth. As China emerges as a great centre of science and technology, it will be taking up a role which it played centuries ago as a leading industrial innovator (Needham 1954). India was never 
so important in this respect, although at one time it was also a major innovator in certain fields such as textiles.

\section{Comparative advantage}

As China and India become richer their comparative advantage will alter. Productivity will rise across the board, but it will probably increase fastest in "knowledge-intensive" goods and services, and least in "labour-intensive" items. There may also be shifts in the pattern of earnings. Chinese and Indian universities are educating huge numbers of graduates and their current surplus of uneducated workers will eventually be depleted, sooner in China perhaps than India. As a result, the relative pay of uneducated workers is likely to increase in the future as compared to that of more educated workers. Thus, labour intensive activities may experience both lower than average productivity growth and higher than average wage growth. If this happens, the relative cost of labour intensive products and their prices will rise as compared to those of knowledge intensive products. According to the theory of comparative advantage, such a shift in the internal structure of unit costs should be accompanied by a shift in the terms and pattern of international trade. As labour intensive products become relatively more expensive, the rich importing countries may be compelled to pay more of their own output to purchase them and thereby suffer a loss of real income. Alternatively, the importing countries may reduce their imports of labour intensive products and seek more costly domestic substitutes instead. Either way, the rich countries will lose. This issue has been investigated theoretically by Paul Samuelson (2004). The appendix to this paper extends his analysis using a simple model and numerical example.

The above shift in comparative advantage will not take place in one go but will occur gradually. As China and India move up the productive hierarchy through progressively more sophisticated export activities, this will create an opportunity for other developing countries to expand their labour intensive exports to the rich countries. This will help to slowdown a shift in terms of trade against the rich countries thereby helping to offset the loss due to the economic development of China and India. Eventually, when the whole world is highly developed, labour intensive activities may return to present rich countries, but this is a long time in the future. In the meantime, the rich countries will continue to import labour intensive products on a large scale, but their sources of supply will shift around the globe in line with shifting comparative advantage. This will help to keep down the cost of such products for the rich importing countries. Another factor to consider is that as China and India grow their demand for sophisticated products from the existing advanced economies will also grow. They will be powerful competitors, but they will also provide large and expanding markets for the goods and services that we produce.

The Flying Geese Theory of Akamatsu (Ozawa 2005) predicts that, as China gets richer, it will gradually phase out it exports of clothing and other labour intensive goods whose production will be relocated in other countries. In this respect it will follow the precedent of such countries as South Korea, which fifteen year ago was still huge exporter of clothes, but is now on the verge of becoming a net importer of these items. The situation is somewhat different in the case of India. Despite its low per capita income, India is not at present a large exporter of labour-intensive manufactures, and the Flying Geese Theory implies that such exports should grow rapidly in the near future as India's mass of cheap rural labour is mobilised (Mayer and Wood 2001). However, the picture is complicated by the fact that India is already a significant exporter of IT-related services and advanced manufactures, and such exports are booming. For this reason, exports of labour-intensive manufactures are never likely to enjoy the same importance for India as they have for China or Korea. If China continues to 
grow rapidly, it will eventually provide a huge market for the labour-intensive manufactures of less developed countries. This would be of great benefit to a continent like Africa which will never grow rich on agriculture, minerals and tourism alone. In accordance with the Flying Geese theory, China will stimulate economic growth well beyond its own frontiers. The same will also be true of India one day, but that will take longer.

If the growth of China and India causes the terms of trade to shift against the advanced economies, how large might this loss be? In 2004, clothing imports into the advanced economies ranged were in the region of 0.5-0.6 per cent of GDP. If clothing imports were to double in price over a period of years the impact on real incomes would be negligible. Of course, there are many other labour intensive imports in addition to clothing, and some high-tech imports have a significant labour intensive component. There are no precise statistics available, but suppose that the labour intensive component of goods and service imports from developing countries costs around 2.5 per cent of GDP for the average advanced economy. Allowing another 2.5 per cent for fuels and minerals yields a total figure equal to 5 per cent of GDP. This indicates the direct loss that would occur if all such items were to double in price because of Chinese and Indian growth. Such a loss would be quite severe if it came all at once, but spread over many years it would have only a marginal impact. For example, suppose that the USA were to experience a loss equal to 5.0 per cent of GDP spread over a period of 25 years. Then, instead of growing at its normal annual rate of 1.8 per cent, per capital income would grow at 1.6 per cent. Instead of rising by 56 per cent over a 25 year period, per capita income would rise by 49 per cent. The effect would be similar in other advanced economies. These economies could absorb a gradual loss of this magnitude without much difficulty. Besides, they are now rich and have reached the point where further increases in per capita income make a comparatively small difference to human happiness (Figure 5).

Another factor to consider is that as China and India grow their demand for sophisticated products from the existing advanced economies will also grow. They will be powerful competitors, but they will also provide large and expanding markets for the goods and services that we produce.

The main worry is not that the growth of China and India will impose a huge terms of trade loss on the advanced economies. Of more concern is the possibility that the entry of these two giants onto the world stage may provoke structural changes which are very harmful to particular subgroups of people, even though their aggregate effect on national income is quite small.

\section{Absolute advantage}

In the course of economic development, there is often a widespread increase in productivity which embraces virtually all sectors of the economy. If wages lag systematically behind productivity growth the result will be a universal reduction in real unit costs. The effect of this on the rich importing countries depends on what happens to the exchange rate. If the exchange rate is rigid then a universal reduction in unit costs will make all exports from the developing country more competitive in international markets. This will cause exports of all kinds to increase and will constrain the growth of imports, resulting in a huge trade surplus such as we have recently observed in China (Figure 6). In the long run, a trade surplus on such a scale is not sustainable and the currency must eventually appreciate. When this occurs, the initial trade advantage of low unit costs is eliminated. Unit costs may remain low in local prices, but the high exchange rate will increase these costs in terms of foreign currency. 
Figure 5

Happiness and Per Capita Income



Figure 6

CHINA AND INDIA: CURRENT ACCOUNT BALANCE 1980-2005

Per cent of GDP

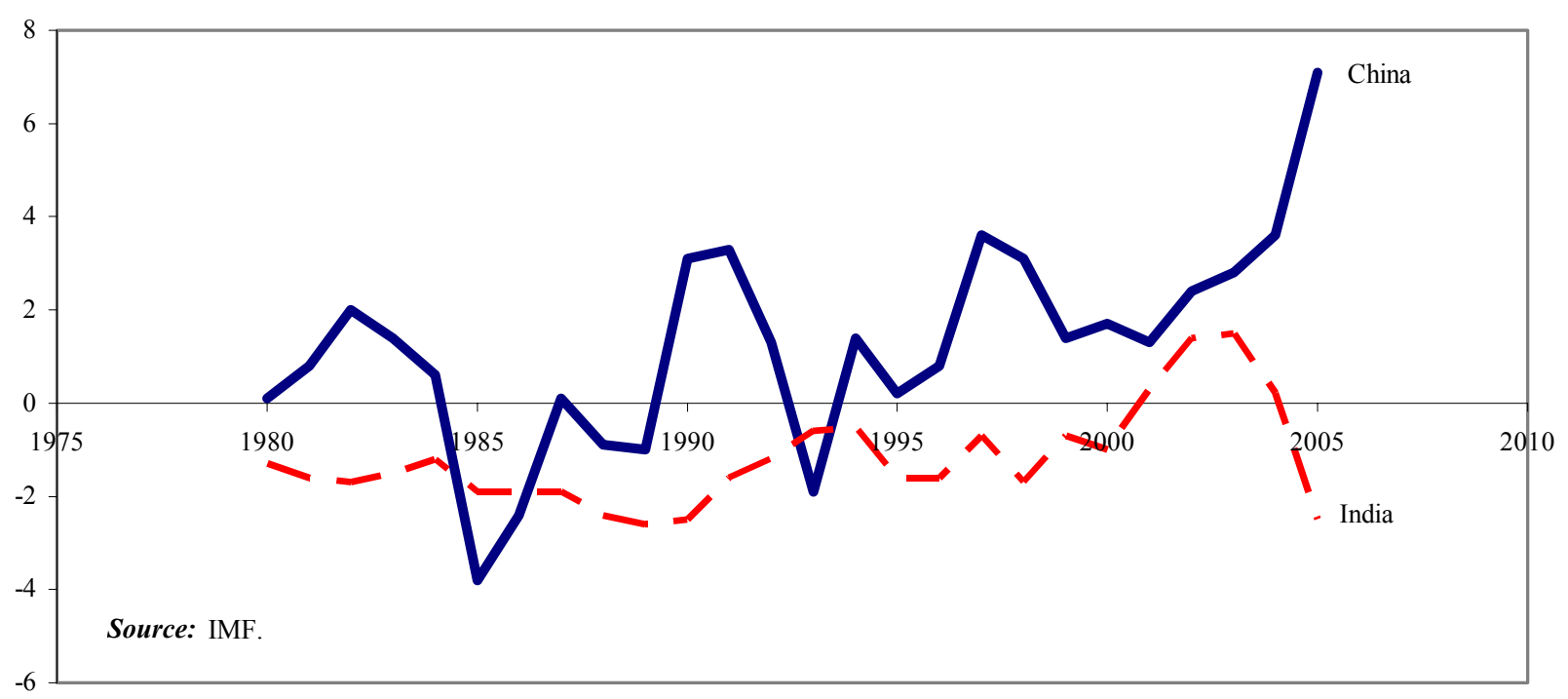


By definition, a uniform reduction in unit costs in the developing country has no effect on relative costs of production and hence its effect on relative prices will normally be of second order. Indeed, there may be no change at all in relative prices. This is the case in the simple two country model of international trade that is presented in Appendix 2. In this model, one of the trading partners is a developed country (the North) and the other is a developing country (the South). The mark-up of prices over unit costs in the South is the same in all sectors of the economy, which ensures that relative prices are unaffected by uniform changes in local unit costs. Moreover, the exchange rate adjusts so as to preserve equality between imports and exports, and there is no change in the volume or composition of international trade. Each country sells just as much of each product as it did before the change in unit costs and hence their terms of trade are unaffected.

In the above example, a uniform reduction in unit costs in the South has no immediate impact on its Northern trading partner. However, this is only part of the story. As unit costs in the South fall (compared to prices), the result is an increase in the local rate of profit. Higher profits make the South more desirable as a location for production and may attract investment from the North. Alternatively, firms in the North may use the threat of relocation to the South as a bargaining counter to persuade their own workers to accept lower wages. Thus, firms that might have invested in, for example, the United States may decide that China is now more profitable and therefore cut back on their American activities. Or they may use the threat of moving to China as a means to reduce the pay of their American employees. Such issues have been explored by Richard Freeman (2005a, b). His thesis is that the opening up of China and India has effectively doubled the global labour supply that is available to capitalist firms, thereby strengthening the hand of capital against labour.

There is no doubt that the potential for investment in China and India is enormous. A recent UNCTAD survey of business and expert opinion indicate that these are amongst the most attractive countries in the world in which to invest (Table 2), and they could become even more attractive as they become more familiar to outside firms and their domestic markets expand. Indeed, the prospect of locating in large and fast growing markets is likely to become the main reason for outside firms to invest in China and India in the coming decades. It is conceivable that rising investment in these countries could lead to a global shortage of savings, causing world interest rates to rise and choking off investment in the advanced economies. This is certainly a theoretical possibility, but it has not happened yet. At the present time, the combined economies of China and India have a current account surplus and they are a net provider of savings to the rest of the world. Alternatively, it might happen one day that transnational firms do not have the managerial capacity to invest simultaneously on a very large scale in many different economies at once. Faced with a choice between China, India and the advanced economies in the future, they may give priority to the former and cut back on the advanced economies so as to avoid managerial overstretch. This is an intriguing idea, but how important it will be in practice remains to be seen.

To what extent does the possibility of investing in China and India influence the bargaining power of employers in the advanced economies? If a firm can obtain much higher profits in China and India than in the advanced economies, it may either move to one of these countries or use the threat of relocation to extract wage and other concessions from its current workforce at home. So much is obvious. The practical question is whether it is really true that firms can make much higher profits in China and India than in the existing advanced economies? Some individual firms certainly can, but there must also be many firms that still find it profitable to invest in the advanced economies, for otherwise how do we explain existing investment behaviour? The advanced economies still attract far more direct investment than goes to China and India. The World Investment Report estimates that over 
the period 2002-2004, these attracted nearly 70 per cent of global direct investment flows and more than 6 times as much as China, including Hong Kong, and India combined (UNCTAD 2006b, Annex table B1). Moreover, the Chinese figure is somewhat inflated by is "round-tripping", whereby funds originating in mainland China are sent abroad and then, disguised as foreign capital, are re-invested China where they are classified as FDI. The flow statistics suggest that the share of China in new direct investment has been rising, but this is not reflected in the stock statistics which show that share of China in the world stock of inward direct investment has fallen from 11.2 per cent in 2000 to 7.9 per cent in 2004 (UNCTAD 2005, Annex table B2). This fall was mainly accounted for by Hong Kong, but there has been some decline in the rest of China. During the period 2002-2004, the share of India in world FDI was less than 1 per cent.

Table 2

Most ATtractive GLOBAL BUSINESS LoCations: RESPONSES OF EXPERTS AND TRANSNATIONAL CORPORATIONS*

\begin{tabular}{llll}
\hline \multicolumn{2}{c}{ Responses from experts } & & Responses from corporations \\
\hline 1. & China $(85 \%)$ & 1. & China $(87 \%)$ \\
2. & United States $(55 \%)$ & 2. & India $(51 \%)$ \\
3. & India $(42 \%)$ & 3. & United States $(51 \%)$ \\
4. & Brazil $(24 \%)$ & 4. & Russian Federation $(33 \%)$ \\
5. & Russian Federation $(21 \%)$ & 5. & Brazil $(20 \%)$ \\
6. & United Kingdom $(21 \%)$ & 6. & Mexico $(16 \%)$ \\
7. & Germany $(12 \%)$ & 7. & Germany $(13 \%)$ \\
8. & Poland $(9 \%)$ & 8. & United Kingdom $(13 \%)$ \\
9. & Singapore $(9 \%)$ & 9. & Thailand $(11 \%)$ \\
10. & Ukraine $(9 \%)$ & 10. & Canada $(7 \%)$ \\
\hline
\end{tabular}

Source: UNCTAD World Investment Report 2005.

* Countries are ranked according to the number of responses that rated each as the most attractive location.

Table 3

INTERNATIONAL WAGE COMPARISON (Measured in US dollars at current exchange rates) $U S A=100$

USA 2004

India 2004

China 2004

China average urban 2002

China average TVE $2002^{*}$

Shanghai municipality urban 2002

Sources: The 2004 figures are based on Mercer Consulting (2005); The 2002 figures are for hourly compensation in manufacturing and are based on Banister (200b), Table 4 and BLS data.

* TVE $=$ town and village enterprises.
100

\section{1}

7.1 earn

T). If there were no international differences in productivity, such a huge gap in wage rates would imply that profit rates in China and India were truly gigantic and it would be a mystery why

so much investment still occurs in the advanced economies. In reality, of course, productivity is often much lower in China and India, and the advantages of low wages may be largely offset by the fact that output per worker is also low. 
There are two reasons why Chinese wages are so low when measured in current dollars. Real wage rates in China are much lower than in the advanced countries, and the cost of living, measured in dollars, is also very low. The standard PPP method used for international comparisons of real income indicates that, measured in dollars, prices within China are on average around a quarter of the US level, whereas real wages are less than one sixth. Neither of these conditions will last. Real wages have been increasing rapidly and this growth should continue in the future (Figure 7). Moreover, because of domestic price inflation and future currency revaluation the Chinese cost of living, measured in dollars should also increase. This is what always happens when poor countries develop. Like China, they begin with a very low cost of living, measured in dollars, but as they get richer the dollar cost of living increases until eventually it approximates the level observed in the advanced economies. Such convergence is widely agreed to be a manifestation of Baumol's "cost disease" (Baumol 1967) and is caused by the failure of lagging sectors, such as construction and local services, to match the rapid productivity growth observed in dynamic export sectors such as manufacturing. Large wage increases in the dynamic sectors spill over into the lagging sectors and are mostly passed on to consumers in the form of higher prices. The operation of this mechanism in China has been confirmed in a recent study by Qin (2006) who finds that economic growth is leading to serious inflationary pressures in labour intensive service industries. The Chinese government has also announced plans to strengthen the legal rights of workers which may add further to cost pressures (Buckley 2006).

Table 4

Real Wages AND Dollar Wages: A Numerical EXAMPLE

(Percentage annual growth rates)

\begin{tabular}{lccc}
\hline & China & USA & China - USA \\
\hline $\begin{array}{l}\text { (1) Cost of living in dollars } \\
\text { (2) Real wage rate }\end{array}$ & 5.5 & 2 & 3.5 \\
$\begin{array}{l}\text { (3) Wage rate in dollars } \\
{[=(1)+(2)]}\end{array}$ & 12 & 1.5 & 5 \\
\hline
\end{tabular}

Table 4 provides a hypothetical example to illustrate how these various factors might combine. In this example, consumer prices measured in dollars, increase 3.5 per cent a year faster in China than America. It is also assumed that real wages are rising at 5 per cent a year faster in China. For this to happen, dollar wage rates in China must grow about 8.5 per cent a year more than American wages.

If the above growth rates could be sustained over a long period of time, they would have a dramatic effect on relative wages in the two countries. Measured in dollars, the hourly compensation of the average urban manufacturing worker in China in 2002 was only 4.4 per cent of the US average (Table 3 ). With the assumed growth rates, the dollar wage rate of such a worker in 2025 would be 29 per cent of the American level. For a Shanghai worker the figure might be somewhat higher. Although hypothetical, this example is not unrealistic. It puts a question mark over the argument that productivity in China will outstrip wages and that profit rates will continue to increase. On the contrary, it is more likely that in certain regions of China rising wages will begin to squeeze profits.

On the available information it is difficult to judge whether there is a latent profit squeeze in China. Some weak evidence is provided by the fact that real wages, in manufacturing at least, have been rising much faster than GDP per capita in recent years (Figure 7). However, a recent OECD survey of Chinese business found that profit rates in the private sector have been rising strongly and are now apparently very high by international standards (Figure 8). According to this survey, in 2003 in China the average rate of return on physical capital in private industrial companies was 15.0 per cent, whereas national accounts data indicate that the equivalent rate of return for non-financial corporations 
Figure 7

GDP PER CAPITA AND URBAN MANUFACTURING WAGES

$1990=100$

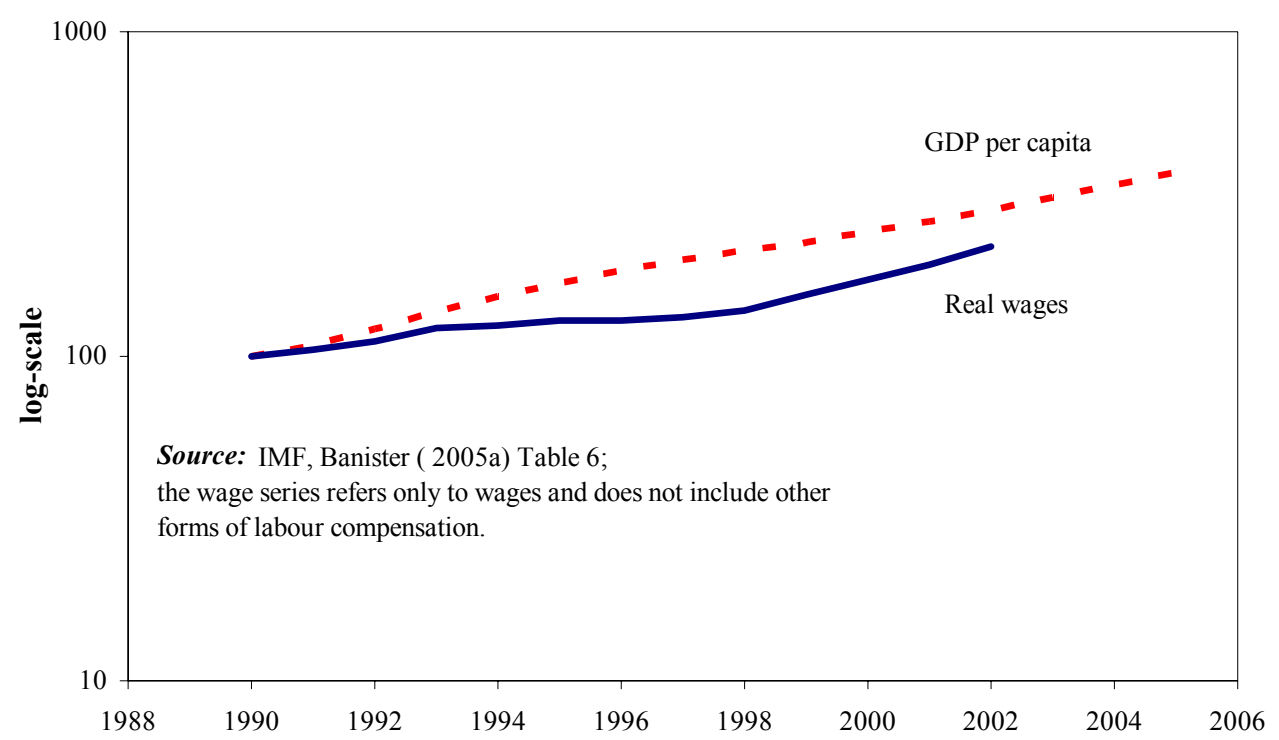

Figure 8

FINANCIAL PERFORMANCE OF INDUSTRIAL COMPANIES

Rates of return on physical assets

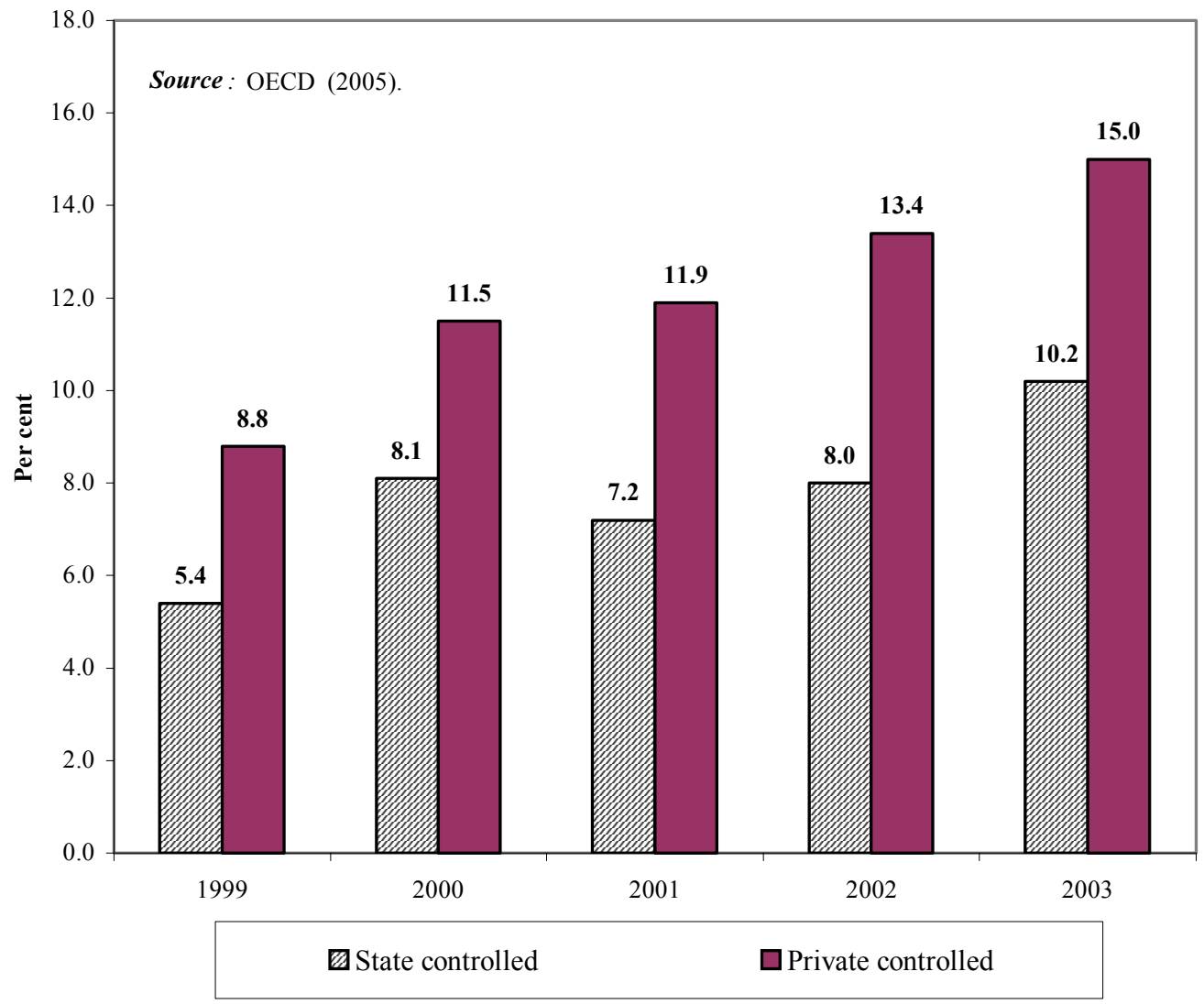


in most OECD countries is in the range 6-12 per cent (Glyn 2006, Chapter 6). Such comparisons must be treated with caution. The rates of return in question may not refer to exactly the same thing, measurement conventions may be different, the Chinese business environment may be riskier, present Chinese profit rates may be a poor guide to the future since wages are increasing so rapidly, and average profit rates may not be a good indication of the return that is available on marginal projects. Despite these qualifications, it does seem to be the case that investment in China is at present highly profitable and that rates of return have been increasing. The question is how long this will continue? Ultimately the answer will depend on what happens to wages and productivity. If dollar wages increase fast enough, then despite continued productivity growth Chinese profits margins will fall, albeit from a high level. In the above numerical example, dollar wages were assumed to grow at 8 per cent a year faster than in the United States. It is hard to believe that, over a prolonged period of time, productivity growth could be sufficient to offset relative wage increases of this magnitude.

\section{Concluding remarks}

The renaissance of China and India will have economic costs and benefits for today's advanced economies. There may be a terms of trade loss as fuels, minerals, and labour intensive goods and services become more expensive. However, although potentially large in absolute terms, this loss is likely to be quite small in comparison to the total output of the advanced economies. If spread over a long period of time, it could be absorbed without too much difficulty. Moreover, as China and India become richer they will invest more in research and development, thereby promoting the discovery of new technologies that can be used by the existing advanced economies. In addition, China and India will provide huge markets for the exports of the existing developed countries, thereby stimulating international specialisation and promoting both static and dynamic economies of scale. Such benefits may be large enough to outweigh the terms of trade loss caused by the higher cost of natural resources and labour intensive imports.

Another potential loss is in the realm of investment. If there are financial or managerial constraints on the overall scale of global investment, it is possible that firms will prefer to invest in China and India rather than in the existing advanced economies. If this occurs on a large scale, which is by no means certain, it will force governments in the advanced economies to find ways to increase savings or of making these economies more attractive as a location for investment. Even if there is not much actual diversion of investment to China and India, the threat of relocation may become a powerful bargaining tool that employers can use against their workers. In aggregate terms, it is uncertain how far the growth of China and India will damage the existing advanced economies. However, it is certain to provoke structural changes that are harmful to particular subgroups of people. Economists tend to regard such effects as temporary adjustment costs, but it is clear from the modern experience of deindustrialisation that the effects of structural change may last for generations and be very painful to the communities involved. Dealing with structural change in a humane fashion may be the greatest economic challenge posed by the rise of China and India. 


\section{BIBLIOGRAPHY}

Banister J (2005a). Manufacturing employment in China. Monthly Labor Review, July, pp. 11-29.

Banister J (2005b). Manufacturing earnings and compensation in China. Monthly Labor Review, August, pp. $22-40$.

Baumol WJ (1967). Macroeconomics of unbalanced growth: the anatomy of urban crisis. American Economic Review, 57:451-426.

Buckley C (2006). Foreign investors may quit if China tightens up labour law. The Times, 19 June.

Das G (2006). The Indian Model. Foreign Affairs, July-August.

Dasgupta S and Singh A (2005). Will services be the new engine of Indian economic growth. Development and Change, 36(6):1035-1057.

Freeman R (2005a). Does globalization of the scientific/engineering workforce threaten U.S. economic leadership. NBER Working Paper 11457.

Freeman R (2005b). China, India and the doubling of the global labor force. http://www.zmag.org/ content/print_article.cfm?itemID $=8167 \&$ sectionID $=1$.

Glyn A (2006). Capitalism Unleashed. Oxford, Oxford University Press.

Ingelhardt R and Klingemann HD (2002). Genes, Culture, Democracy and Happiness. World Values Survey website.

Joshi S (2004). Tertiary sector-driven growth in India: impact on employment and poverty", Economic and Political Weekly 39(37):4175-4178.

Kennedy P (1988). The Rise and Fall of the Great Powers: Economic Change and Military Conflict from 1500 to 2000. London, Unwin Hyman.

Maddison A. (2001). The World Economy: A Millennial Perspective, OECD.

Mayer J and Wood A (2001). South Asia's export structure in a comparative perspective. Oxford Development Studies, 29(1):5-29.

Mercer Consulting (2005). European survey of employment costs. http://www.mercerhr.com/pressrelease/ details.jhtml/dynamic/idContent/1175865.

Needham J (1954). Science and Civilisation in China, Volume 1. Cambridge, Cambridge University Press.

OECD (2005). Economic Survey of China.

Ozawa T (2005). Institutions, Industrial Upgrading, and Economic Performance in Japan - The 'Flying-Geese Paradigm of Catch-up Growth. Northampton, Massachusetts: Edward Elgar Publishing.

Qin D (2006). Is China's growing service sector leading to cost disease? Structural Change and Economic Dynamics, 17(3):267-287.

Samuelson PA (2004). Where Ricardo and Mill rebut and confirm arguments of mainstream economists supporting globalization. Journal of Economic Perspectives, 18(3):135-146.

UNCTAD (2005a). Trade and Development Report 2005. United Nations publication, Sales No. E.05.II.13, New York and Geneva.

UNCTAD (2005b). World Investment Report 2005. United Nations publication, Sales No. E.05.II.D.10, New York and Geneva.

Wood A (1994). North-South Trade, Employment and Inequality: Changing Fortunes in a Skill-Driven World, Oxford, Clarendon Press. 


\section{Appendix 1 \\ PROJECTED ChINESE AND INDIAN GROWTH}

This appendix describes how the projections shown in Figure 2 were derived. Table 5 shows relative per capita incomes in 2004 and the growth rates of per capita GDP over the period 1990-2004.

Table 5

CATCHING UP WITH THE USA: GDP PER CAPITA

\begin{tabular}{|c|c|c|c|}
\hline & $U S A$ & China & India \\
\hline $\begin{array}{l}\text { Per capita GDP in } 2004 \text { as per cent of USA } \\
\text { (measured at Purchasing Power Parity) }\end{array}$ & 100 & 14.9 & 7.9 \\
\hline Annual growth rate 2000-2004 & $1.8 \%$ & $8.4 \%$ & $4.6 \%$ \\
\hline $\begin{array}{l}\text { Time needed to catch up with USA } \\
\text { (with above growth rates) }\end{array}$ & & 30 years & 95 years \\
\hline
\end{tabular}

Projection is based on equations of following type

$-\frac{d y}{d t}=-\beta y \quad$ where $y=\log \left(\frac{Y}{Y_{U S A}}\right)$ and $Y=$ GDP per capita (at PPP).

Using data for the period 2000-2004 the following coefficients were estimated:

China: $\beta=.031$

India: $\beta=.010$

The future growth of GDP per capita is projected using the following coefficients:

China: $\beta=.031$

India: $\beta=.025$

The coefficient for China is the same as the historical one; the coefficient for India is substantially higher than the historical one, reflecting the assumption that India is moving towards a Chinese-style trajectory.

Future population growth is projected using the UN Population Division (2002 revision) medium variant.

\section{Market Exchange Rates}

GDP at the market exchange rate is derived as follows.

Let $\bar{y}=\log \left(\frac{\bar{Y}}{\bar{Y}_{U S A}}\right)$ where $\bar{Y}=$ GDP in current US dollars (at the market exchange rate) $r=\log (R)$ where $R=\frac{\text { market exchange rate }}{\text { PPP exchange rate }}$ 
By definition

$$
\begin{aligned}
& \frac{\bar{Y}}{\bar{Y}_{U S A}}=R\left(\frac{Y}{Y_{U S A}}\right) \\
& \bar{y}=r+y
\end{aligned}
$$

We assume that $r=\alpha y$ for some constant $\alpha$. This ensures that $r=0$ when $\mathrm{y}=0$. Hence, $\mathrm{R}=1$ when $\mathrm{Y}=\mathrm{Y}_{\text {USA }}$. The market exchange rate and the PPP exchange rate therefore converge to the same value as per capita income converges to the US level. The value of $\alpha$ is estimated using the following equation

$\alpha=\frac{r_{2004}}{y_{2004}}$. 


\section{Appendix 2}

\section{A Simple Model AND NUMerical EXAMPLE}

This section presents a simple model designed to illustrate how changes in wage rates and technology in developing countries (the South) may affect their trading partners in the advanced economies (the North). The model seeks to embody within a single framework the insights of Samuelson (2004) and Freeman $(2005 \mathrm{a}, \mathrm{b})$. To this end, it distinguishes between uniform changes in wages and technology that affect all sectors by the same proportionate amount, and changes whose impact is uneven so that some sectors are more affected than others.

There are two countries "North" and "South", labelled N and S respectively, and two goods labelled 1 and 2. Good 1 is skill-intensive and good 2 is labour-intensive. Following Wood (1994), it is assumed that the North has entirely abandoned the production of good 2 because it is no longer profitable and now produces only good 1 , whereas the South produces both goods. The North exports some of its output of good 1 in return for imports of good 2 from the South. The exchange rate adjusts so as to ensure that exports and imports are equal in value. Transport costs are zero and there are no trade barriers of any kind. As a result, prices in each country are the same when measured in a common currency. Let $p_{1}$ and $p_{2}$ be the prices of goods 1 and 2 .

Real incomes are derived by deflating monetary incomes as follows. All individuals, wherever they are located, are assumed to have the following utility function

$$
U=2 \sqrt{C_{1} C_{2}}
$$

where $C_{1}$ and $C_{2}$ are the amounts of good 1 and good 2 consumed. Consider an individual with a monetary income of $M$ which is spent in such a way as to maximise utility at the prevailing prices. It is easy to show that the above utility function is maximised when

$$
\begin{aligned}
& C_{1}=\frac{M}{2 p_{1}} \\
& C_{2}=\frac{M}{2 p_{2}}
\end{aligned}
$$

The resulting utility is given by

$$
U=\frac{M}{\sqrt{p_{1} p_{2}}}
$$

The quantity $U$ can be taken as a measure of real income. It is derived by deflating monetary income $M$ by the geometric mean of prices $\sqrt{p_{1} p_{2}}$. 
The above utility function implies that all individuals divide their expenditure equally between the two goods. Aggregating across all individuals in the North, this implies that half of the North's monetary income is spent on the home produced good 1 and the other half will be spent on imports of good 2 . Let $Y_{N, 1}$ be the total amount of good 1 produced in the North. Since this country produces nothing else, the monetary income of the North is equal to $p_{1} Y_{N, 1}$. Aggregating across all individuals in the North yields the following amounts for total consumption

$$
\begin{aligned}
& C_{N, 1}=\frac{p_{1} Y_{N, 1}}{2 p_{1}}=\frac{Y_{N, 1}}{2} \\
& C_{N, 2}=\frac{p_{1} Y_{N, 1}}{2 p_{2}}=\frac{Y_{N, 1}}{2}\left(\frac{p_{1}}{p_{2}}\right)
\end{aligned}
$$

These equations imply that

$$
\begin{aligned}
& \text { value of exports }=p_{1}\left(Y_{N, 1}-C_{N, 1}\right)=\frac{p_{1} Y_{N, 1}}{2} \\
& \text { value of imports }=p_{2} C_{N, 2}=\frac{p_{1} Y_{N, 1}}{2}
\end{aligned}
$$

The terms of trade are given by

$$
\frac{\text { volume of imports }}{\text { volume of exports }}=\frac{C_{N, 2}}{Y_{N, 1}-C_{N, 1}}=\frac{p_{1}}{p_{2}}
$$

Let $\bar{Y}_{N}$ be the aggregate real income (utility) of the North. This can be derived by deflating aggregate monetary income as follows

$$
\bar{Y}_{N}=\frac{p_{1} Y_{N, 1}}{\sqrt{p_{1} p_{2}}}
$$

Thus,

$$
\bar{Y}_{N}=Y_{N, 1} \sqrt{\frac{p_{1}}{p_{2}}}
$$

This formula indicates that any increase in $p_{2} / p_{1}$ (the relative price of labour-intensive good 2 will harm the North. This is because the North obtains fewer imports of good 2 in return for its exports of $\operatorname{good} 1$.

The terms of international trade are determined by conditions of production in the South. Assume that production takes place under constant returns to scale and that labour is the only input. Let $\ell_{S, 1}$ and $\ell_{S, 2}$ be the amounts of labour required in the South to produce a single unit of goods 1 and 2 , respectively. Let $w_{S, 1}$ and $w_{S, 2}$ be the money wage rates in sectors 1 and 2 . Real wage rates are then 
given by

$$
\begin{aligned}
& \bar{w}_{S, 1}=\frac{w_{S, 1}}{\sqrt{p_{1} p_{2}}} \\
& \bar{w}_{S, 2}=\frac{w_{S, 2}}{\sqrt{p_{1}} p_{2}}
\end{aligned}
$$

Suppose that production takes one period and that wages are advanced to workers at the beginning of the period. Since labour is the only input, advanced wages are the only form of financial investment that a firm makes. The rate of profit is therefore equal to profits divided by wages. In this model, the rate of profit is equal the mark up of price over cost of production. Assume that capital mobility equalises profits rates across sectors in the South and let $\pi_{S}$ be the resulting uniform profit rate. This assumption implies that

$$
\begin{aligned}
& p_{1}=\left(1+\pi_{S}\right) w_{S, 1} \ell_{S, 1} \\
& p_{2}=\left(1+\pi_{S}\right) w_{S, 2} \ell_{S, 2}
\end{aligned}
$$

Hence,

$$
\frac{p_{1}}{p_{2}}=\frac{w_{S, 1} \ell_{S, 1}}{w_{S, 2} \ell_{S, 2}}
$$

Substituting in (3) it follows that

$$
\bar{Y}_{N}=Y_{N, 1} \sqrt{\frac{w_{S, 1} \ell_{S, 1}}{w_{S, 2} \ell_{S, 2}}}
$$

Let $\ell_{N, 1}$ and $\ell_{N, 2}$ be the amounts of labour required in the North to produce a single unit of goods 1 and 2, respectively, and let $w_{N, 1}$ and $w_{N, 2}$ be the corresponding money wage rates. Since good 2 is not actually produced in the North, $w_{N, 2}$ must be interpreted as the wage that employers would have to pay if production of this good did take place. It is assumed that $p_{2}<w_{N, 2} \ell_{N, 2}$. This ensures the cost of producing good 2 is greater than its selling price, which is consistent with the fact that the North does not produce this good. The rate of profit in sector 1 in the North satisfies the following equation

$$
p_{1}=\left(1+\pi_{N}\right) w_{N, 1} \ell_{N, 1}
$$

This completes the model.

In the above model, the impact of trade on the North comes entirely through relative prices, which in turn reflect relative costs of production within the South. The absolute level of costs is irrelevant. A uniform proportionate increase or reduction in southern costs will not affect relative prices and hence 
will have no affect on the terms upon which international exchange takes place. However, it will affect the rate of profit in the South and this may have an indirect effect on the economy of the North. For example, suppose that productivity in the South increases faster than wages. This will raise the rate of profit in the South and may attract capital that would otherwise be invested in the North. Alternatively, firms within the North may use the threat of relocation to the South to reduce wages in the North and increase their own profits.

\section{A numerical example}

To explore these issues further we shall consider a simple numerical example based on the above model. This is laid out in Table 6. The first column of the Table 4 shows the amounts of labour initially required per unit of output in each sector in each country, together with prices, nominal wages, real wages and profit rates. The remaining columns show the effect of progressive modifications to some of the parameters. Modifications are shown in bold. In each column, the profit rate in the South is the same in both sectors. Prices are measured in a common currency and are uniform across countries. The table also shows output in each sector in country $\mathrm{N}$. This is equal to zero in sector 2 indicating that country $\mathrm{N}$ only produces good 1 . With the assumed prices, wage rates and productivity, the profit rate in the North in sector 2 would be negative. This justifies the assumption that production in this sector is equal to zero. The last row shows aggregate real income in the North.

In the shift from column (1) to column (2) the amount of labour required per unit of output is reduced by one-fifth in each sector in the South. Labour productivity in the North remains the same, and there is no change in money wage rates or prices in either country. As a result, real wage rates in North and South are unaltered. Aggregate real income in the North is also unaffected. The profit rate in the North remains at 20 per cent but the profit rate in the South increases to 50 per cent. This example illustrates how a uniform reduction in costs in the South has no effect on relative prices and leaves real income and profits in the North unaffected. However, it does increase the rate of profit in the South. The appearance of this profit differential increases the bargaining power of employers in the North vis-àvis their workers, since they can threaten to relocate their production in the South unless workers accept lower wages. Column (3) shows what happens if workers in the North accept lower wages. It is assumed that wages in the North are reduced by a sufficient amount to equalise rates of profit in the two countries. This does not affect the aggregate real income of the North, but it does lead to a redistribution of income from labour to capital. These comparisons illustrate how uniform changes in costs within a country leave the terms of international trade unaffected. However, they may affect other countries indirectly through their influence on profit rates and thereby investment. This illustrates the principle of absolute advantage. 
Table 6

COMParative ANd AbSOlute AdVANTAge: A Numerical EXAMPle

\begin{tabular}{|c|c|c|c|c|c|}
\hline & (1) & (2) & (3) & (4) & (5) \\
\hline$\ell_{S .1}$ & 5.0 & 4.0 & 4.0 & 4.0 & 3.5 \\
\hline$\ell_{S, 2}$ & 10.0 & 8.0 & 8.0 & 8.0 & 8.0 \\
\hline$\ell_{N .1}$ & 1.0 & 1.0 & 1.0 & 1.0 & 1.0 \\
\hline$\ell_{N, 2}$ & 3.0 & 3.0 & 3.0 & 3.0 & 3.0 \\
\hline$w_{S .1}$ & 2.0 & 2.0 & 2.0 & 2.0 & 2.0 \\
\hline$w_{S, 2}$ & 1.0 & 1.0 & 1.0 & 1.2 & 1.2 \\
\hline$w_{N .1}$ & 10.0 & 10.0 & 8.0 & 8.0 & 7.0 \\
\hline$w_{N, 2}$ & 8.0 & 8.0 & 6.4 & 6.4 & 5.6 \\
\hline$p_{1}$ & 12.0 & 12.0 & 12.0 & 12.0 & 10.5 \\
\hline$p_{2}$ & 12.0 & 12.0 & 12.0 & 14.4 & 14.4 \\
\hline $\bar{w}_{S .1}$ & 0.17 & 0.17 & 0.17 & 0.15 & 0.16 \\
\hline $\bar{w}_{S, 2}$ & 0.08 & 0.08 & 0.08 & 0.09 & 0.10 \\
\hline $\bar{w}_{N .1}$ & 0.83 & 0.83 & 0.67 & 0.61 & 0.57 \\
\hline $\bar{w}_{N, 2}$ & 0.67 & 0.67 & 0.53 & 0.49 & 0.46 \\
\hline$\pi_{S}$ & 20 & $50 \%$ & $50 \%$ & $50 \%$ & $50 \%$ \\
\hline$\pi_{N}$ & $20 \%$ & $20 \%$ & $50 \%$ & $50 \%$ & $50 \%$ \\
\hline$Y_{N .1}$ & $10^{9}$ & $10^{9}$ & $10^{9}$ & $10^{9}$ & $10^{9}$ \\
\hline$Y_{N 2}$ & 0 & 0 & 0 & 0 & 0 \\
\hline $\bar{Y}_{N}$ & $\begin{array}{ll}10^{9} \times \\
1.00\end{array}$ & $\begin{array}{ll}10^{9} & \times \\
1.00 & \end{array}$ & $\begin{array}{ll}10^{9} & \times \\
1.00 & \end{array}$ & $10^{9} \times 0.91$ & $\begin{array}{l}10^{9} \times \\
0.85\end{array}$ \\
\hline
\end{tabular}

The shift from column (3) to column (4) shows how the North as a whole may be affected by a nonuniform change in production costs in the South. This shift involves an increase in wages in sector 2, perhaps because of a shortage of workers for this labour-intensive industry. Meanwhile, money wages remain unchanged in sector 1 . Because of higher costs in sector 2, there is an increase in the relative price of labour intensive goods causing an unfavourable shift in the terms of trade for the North. In return for its exports of skill intensive goods, the North receives fewer labour intensive goods in return. As a result, aggregate real income in the North falls. This example assumes that real wages fall sufficiently to preserve the old rate of profit in the North. This is not the only assumption. One could alternatively assume that the terms of trade loss is born entirely by the employers, in which case profits will be severely squeezed. In the South the real wages of workers in the labour intensive sector rise whereas those in the skill intensive sector fall. There is thus an internal redistribution of income.

The shift from column (4) to column (5) illustrates what may happen if productivity growth in the South is uneven. There is a reduction in the amount of labour required per unit of output in sector 1, but there is no change in the other sector. Wage rates and the profit rate in the South also remain 
unchanged. As before the relative price of good 1 falls and the terms of trade shift against the North. Aggregate real income in the North is thereby reduced. It is assumed that wages in the North fall sufficiently to preserve the old rate of profit. This illustrates how the North may be harmed by technological advances within the skill-intensive sector of the South.

The above discussion highlights the difference between absolute and comparative advantage. In the cases concerned with absolute advantage, there was a uniform reduction in production costs in the South. This did not directly harm the North, but it did provoke a redistribution of income from labour to capital in the North as employers threatened to relocate production to the now more profitable South. In the cases concerned with comparative advantage, there was a shift in relative production costs within the South. This caused relative prices to change and imposed a terms of trade loss on the North, causing its real income to fall. In a more complex model, one could show how shifts in relative costs in the South may provoke structural change in the North and benefit some types of worker at the expense of others. 
UNCTAD DISCUSSION PAPERS

\begin{tabular}{|c|c|c|c|}
\hline No. & Date & Author(s) & Title \\
\hline 181 & October 2005 & Dr. Michael Sakbani & $\begin{array}{l}\text { A re-examination of the architecture of the } \\
\text { international economic system in a global setting } \\
\text { issues and proposals }\end{array}$ \\
\hline 180 & October 2005 & Jörg Mayer and Pilar Fajarnes & $\begin{array}{l}\text { Tripling Africa's Primary Exports: What? How? } \\
\text { Where? }\end{array}$ \\
\hline 179 & April 2005 & S.M. Shafaeddin & $\begin{array}{l}\text { Trade liberalization and economic reform in } \\
\text { developing countries: structural change or de- } \\
\text { industrialization? }\end{array}$ \\
\hline 178 & April 2005 & Andrew Cornford & Basel II: The revised framework of June 2004 \\
\hline 177 & April 2005 & Benu Schneider & $\begin{array}{l}\text { Do global standards and codes prevent financial } \\
\text { crises? Some proposals on modifying the standards- } \\
\text { based approach }\end{array}$ \\
\hline 176 & December 2004 & Jörg Mayer & $\begin{array}{l}\text { Not totally naked: textiles and clothing trade in a } \\
\text { quota free environment }\end{array}$ \\
\hline 175 & August 2004 & S.M. Shafaeddin & $\begin{array}{l}\text { Who is the master? Who is the servant? Market or } \\
\text { Government? }\end{array}$ \\
\hline 174 & August 2004 & Jörg Mayer & $\begin{array}{l}\text { Industrialization in developing countries: some } \\
\text { evidence from a new economic geography } \\
\text { perspective }\end{array}$ \\
\hline 173 & June 2004 & Irfan ul Haque & Globalization, neoliberalism and labour \\
\hline 172 & June 2004 & Andrew J. Cornford & $\begin{array}{l}\text { The WTO negotiations on financial services: current } \\
\text { issues and future directions }\end{array}$ \\
\hline 171 & May 2004 & Andrew J. Cornford & $\begin{array}{l}\text { Variable geometry for the WTO: concepts and } \\
\text { precedents }\end{array}$ \\
\hline 170 & May 2004 & $\begin{array}{l}\text { Robert Rowthorn and } \\
\text { Ken Coutts }\end{array}$ & $\begin{array}{l}\text { De-industrialization and the balance of payments in } \\
\text { advanced economies }\end{array}$ \\
\hline 169 & April 2004 & Shigehisa Kasahara & $\begin{array}{l}\text { The flying geese paradigm: a critical study of its } \\
\text { application to East Asian regional development }\end{array}$ \\
\hline 168 & February 2004 & Alberto Gabriele & $\begin{array}{l}\text { Policy alternatives in reforming power utilities in } \\
\text { developing countries: a critical survey }\end{array}$ \\
\hline 167 & January 2004 & $\begin{array}{l}\text { Richard Kozul-Wright and } \\
\text { Paul Rayment }\end{array}$ & Globalization reloaded: an UNCTAD Perspective \\
\hline 166 & February 2003 & Jörg Mayer & The fallacy of composition: a review of the literature \\
\hline 165 & November 2002 & Yuefen Li & China's accession to WTO: exaggerated fears? \\
\hline 164 & November 2002 & $\begin{array}{l}\text { Lucas Assuncao and } \\
\text { ZhongXiang Zhang }\end{array}$ & Domestic climate change policies and the WTO \\
\hline 163 & November 2002 & A.S. Bhalla and S. Qiu & $\begin{array}{l}\text { China's WTO accession. Its impact on Chinese } \\
\text { employment }\end{array}$ \\
\hline 162 & July 2002 & Peter Nolan and Jin Zhang & $\begin{array}{l}\text { The challenge of globalization for large Chinese } \\
\text { firms }\end{array}$ \\
\hline 161 & June 2002 & $\begin{array}{l}\text { Zheng Zhihai and } \\
\text { Zhao Yumin }\end{array}$ & $\begin{array}{l}\text { China's terms of trade in manufactures, } \\
1993-2000\end{array}$ \\
\hline
\end{tabular}




\begin{tabular}{|c|c|c|c|}
\hline No. & Date & Author(s) & Title \\
\hline 160 & June 2002 & S.M. Shafaeddin & $\begin{array}{l}\text { The impact of China's accession to WTO on exports } \\
\text { of developing countries }\end{array}$ \\
\hline 159 & May 2002 & $\begin{array}{l}\text { Jörg Mayer, Arunas } \\
\text { Butkevicius and Ali Kadri }\end{array}$ & Dynamic products in world exports \\
\hline 158 & April 2002 & $\begin{array}{l}\text { Y1lmaz Akyüz and } \\
\text { Korkut Boratav }\end{array}$ & The making of the Turkish financial crisis \\
\hline 157 & September 2001 & Heiner Flassbeck & $\begin{array}{l}\text { The exchange rate: Economic policy tool or market } \\
\text { price? }\end{array}$ \\
\hline 156 & August 2001 & Andrew J. Cornford & $\begin{array}{l}\text { The Basel Committee's proposals for revised capital } \\
\text { standards: Mark } 2 \text { and the state of play }\end{array}$ \\
\hline 155 & August 2001 & Alberto Gabriele & $\begin{array}{l}\text { Science and technology policies, industrial reform } \\
\text { and technical progress in China: Can socialist } \\
\text { property rights be compatible with technological } \\
\text { catching up? }\end{array}$ \\
\hline 154 & June 2001 & Jörg Mayer & $\begin{array}{l}\text { Technology diffusion, human capital and economic } \\
\text { growth in developing countries }\end{array}$ \\
\hline 153 & December 2000 & Mehdi Shafaeddin & $\begin{array}{l}\text { Free trade or fair trade? Fallacies surrounding the } \\
\text { theories of trade liberalization and protection and } \\
\text { contradictions in international trade rules }\end{array}$ \\
\hline 152 & December 2000 & Dilip K. Das & Asian crisis: distilling critical lessons \\
\hline 151 & October 2000 & Bernard Shull & $\begin{array}{l}\text { Financial modernization legislation in the United } \\
\text { States - Background and implications }\end{array}$ \\
\hline 150 & August 2000 & Jörg Mayer & $\begin{array}{l}\text { Globalization, technology transfer and skill } \\
\text { accumulation in low-income countries }\end{array}$ \\
\hline 149 & July 2000 & Mehdi Shafaeddin & $\begin{array}{l}\text { What did Frederick List actually say? Some } \\
\text { clarifications on the infant industry argument }\end{array}$ \\
\hline 148 & April 2000 & Yilmaz Akyüz & $\begin{array}{l}\text { The debate on the international financial } \\
\text { architecture: Reforming the reformers }\end{array}$ \\
\hline 146 & February 2000 & $\begin{array}{l}\text { Manuel R. Agosin } \\
\text { and Ricardo Mayer }\end{array}$ & $\begin{array}{l}\text { Foreign investment in developing countries: Does it } \\
\text { crowd in domestic investment? }\end{array}$ \\
\hline 145 & January 2000 & $\begin{array}{l}\text { B. Andersen, Z. Kozul- } \\
\text { Wright and R. Kozul-Wright }\end{array}$ & $\begin{array}{l}\text { Copyrights, competition and development: The case } \\
\text { of the music industry }\end{array}$ \\
\hline 144 & December 1999 & Wei Ge & The dynamics of export-processing zones \\
\hline 143 & November 1999 & $\begin{array}{l}\text { Y1lmaz Akyüz and } \\
\text { Andrew Cornford }\end{array}$ & $\begin{array}{l}\text { Capital flows to developing countries and the } \\
\text { reform of the international financial system }\end{array}$ \\
\hline 142 & November 1999 & Jean-François Outreville & $\begin{array}{l}\text { Financial development, human capital and } \\
\text { political stability }\end{array}$ \\
\hline 141 & May 1999 & $\begin{array}{l}\text { Lorenza Jachia } \\
\text { And Ethél Teljeur }\end{array}$ & $\begin{array}{l}\text { Free trade between South Africa and the European } \\
\text { Union - a quantitative analysis }\end{array}$ \\
\hline 140 & February 1999 & $\begin{array}{l}\text { M. Branchi, A. Gabriele } \\
\text { and V. Spiezia }\end{array}$ & $\begin{array}{l}\text { Traditional agricultural exports, external dependency } \\
\text { and domestic prices policies: African coffee exports } \\
\text { in a comparative perspective }\end{array}$ \\
\hline
\end{tabular}

